\title{
Uremic Toxins and Ciprofloxacin Affect Human Tenocytes In Vitro
}

\author{
Erman Popowski ${ }^{1}$, Benjamin Kohl ${ }^{1}{ }^{(0)}$, Tobias Schneider ${ }^{1,2}$, Joachim Jankowski ${ }^{3,4}$ and \\ Gundula Schulze-Tanzil 4,*(D) \\ 1 Department of Traumatology and Reconstructive Surgery, Campus Benjamin Franklin, \\ Charité-Universitätsmedizin Berlin, Freie Universität Berlin, Humboldt-Universität zu Berlin and Berlin \\ Institute of Health, Hindenburgdamm 30, 12203 Berlin, Germany; e.popowski@web.de (E.P.); \\ benjamin.kohl@charite.de (B.K.); tob.schn@t-online.de (T.S.) \\ 2 Institute of Anatomy, Paracelsus Private Medical University, Nuremberg and Salzburg, Nuremberg, \\ Prof. Ernst Nathan Str. 1, 90419 Nuremberg, Germany \\ 3 Institute for Molecular Cardiovascular Research (IMCAR), RWTH Aachen, Pauwelsstraße 30, 52074 Aachen, \\ Germany; jjankowski@ukaachen.de \\ 4 Experimental Vascular Pathology, Cardiovascular Research Institute Maastricht (CARIM), \\ Maastricht University, 6229 HX Maastricht, The Netherlands \\ * Correspondence: gundula.schulze@pmu.ac.at; Tel.: +49-(0)911-398-6772
}

Received: 6 April 2020; Accepted: 8 June 2020; Published: 14 June 2020

check for updates

\begin{abstract}
Tendinopathy is a rare but serious complication of quinolone therapy. Risk factors associated with quinolone-induced tendon disorders include chronic kidney disease accompanied by the accumulation of uremic toxins. Hence, the present study explored the effects of the representative uremic toxins phenylacetic acid (PAA) and quinolinic acid (QA), both alone and in combination with ciprofloxacin (CPX), on human tenocytes in vitro. Tenocytes incubated with uremic toxins +/- CPX were investigated for metabolic activity, vitality, expression of the dominant extracellular tendon matrix (ECM) protein type I collagen, cell-matrix receptor $\beta 1$-integrin, proinflammatory interleukin (IL)-1 $\beta$, and the ECM-degrading enzyme matrix metalloproteinase (MMP)-1. CPX, when administered at high concentrations $(100 \mathrm{mM})$, suppressed tenocyte metabolism after $8 \mathrm{~h}$ exposure and at therapeutic concentrations after $72 \mathrm{~h}$ exposure. PAA reduced tenocyte metabolism only after $72 \mathrm{~h}$ exposure to very high doses and when combined with CPX. QA, when administered alone, led to scarcely any cytotoxic effect. Combinations of CPX with PAA or QA did not cause greater cytotoxicity than incubation with CPX alone. Gene expression of the pro-inflammatory cytokine IL-1 $\beta$ was reduced by CPX but up-regulated by PAA and QA. Protein levels of type I collagen decreased in response to high CPX doses, whereas PAA and QA did not affect its synthesis significantly. MMP-1 mRNA levels were increased by CPX. This effect became more pronounced in the form of a synergism following exposure to a combination of CPX and PAA. CPX was more tenotoxic than the uremic toxins PAA and QA, which showed only distinct suppressive effects.
\end{abstract}

Keywords: ciprofloxacin; tenocytes; uremic toxins; phenylacetic acid; quinolinic acid; integrin; interleukin-1beta; matrix metalloproteinase-1

\section{Introduction}

The first report concerning the tenotoxicity of quinolone antibiotics was published decades ago [1]. Ciprofloxacin (CPX) is one of the most common drugs associated with this adverse effect [2,3] and has been implicated in quinolone-associated ruptures of various tendons, such as Achilles tendons or those of the triceps brachii, iliopsoas, gluteal, adductor longus, and extensor digitorum communis muscles [2,4-13]. 
Why tendons are particularly prone to the toxic side effects of fluoroquinolones remains unclear. Tendons are a bradytrophic tissue with poor blood supply and low cell content [14]. Most of the cells within tendons are tenocytes, representing specialized fibroblasts. It is likely that the low nutrient exchange exposes tendons to the toxic effects of this class of antibiotics. However, the particular signaling pathways involved in mediating quinolone-driven tenotoxicity, as well as mechanisms of synergistic and additive effects with other therapeutic agents and metabolic conditions, have not been elucidated thus far.

Several hypotheses (Figure 1) have been proposed based on experimental observations associated with quinolones in tendon, such as inhibition of tendon-derived cell proliferation, occurrence of cell cycle arrest, impaired tenocyte migration, and dysregulated ECM synthesis, for example, elevated type III collagen expression (increase in the type III/I collagen ratio) [15-20]. In addition, reduced cell viability, impaired expression of the divalent cation-dependent $\beta 1$-integrin receptors, $\mathrm{N}$-cadherins, and connexins; increased production of several matrix metalloproteinases (MMPs) [21-25] coupled with extracellular tendon matrix (ECM) degradation and oxidative stress [25-27] have previously been implicated in tenotoxicity of quinolones (Figure 1). MRI analysis revealed a loss in glycosaminoglycan (GAG) content induced by CPX [28]. In recent years, some predispositions to quinolones-mediated tendinopathies have been documented, such as treatment with glucocorticoids [29], old age, athletes, and renal insufficiency or transplantation [2,12,30]. In particular, renal insufficiency leads to metabolic dysregulations such as secondary hyperparathyroidism and hypercalcinosis, facilitating tendon ruptures [31-36]. However, renal insufficiency is complex and goes along with the increase of several toxic compounds, so-called uremic toxins, which cannot be fully removed by hemodialysis [37-39]. Moreover, CPX is predominately renally eliminated [40], hence, variable serum concentrations could be expected in patients with chronical kidney diseases and possibly, also an accumulation in the bradytrophic tendon tissue.

Some of these uremic toxins, such as phenylacetic acid (PAA), are partly protein bound, by, for example, binding albumin [41]. PAA is responsible for activating several functions of polymorphonuclear leukocytes, accompanied by the expression of surface activation markers while impairing their apoptotic cell death. Therefore, PAA might be associated with inflammation [42]. It also suppressed macrophage functions [43]. PAA increased reactive oxygen species (ROS) and tumor necrosis factor (TNF) $\alpha$ release in vascular endothelial cells, which are known to contribute to atherosclerosis and blood vessel calcification [44]. PAA inhibited osteoblast proliferation [45]. It diminished inducible nitric oxide synthase (iNOS) expression in mononuclear leukocytes-nitric oxide (NO) released by iNOS activity is known to be protective in atherosclerosis [46].

Another uremic toxin is quinolinic acid (QA), which is increased in uremia [47] and likely responsible for diverse pathological features such as the development of anemia by antagonizing erythropoietin release, mediating some immunosuppression, neurotoxicity, and cardiovascular effects [38,47-49].

However, so far, nothing is known about the direct effect of these uremic toxins on tendon metabolism and their possible interaction with fluoroquinolones. Serum and plasma concentrations of QA and PAA are known to be substantially increased in uremia compared to normal conditions (Table 1), but concentrations in the bradytrophic tissue tendon are so far unknown. Knowledge of the shared mechanisms of fluoroquinolones and uremic toxins might allow tendon ruptures to be obviated and tendon repair strategies to be improved in hemodialysis patients. 


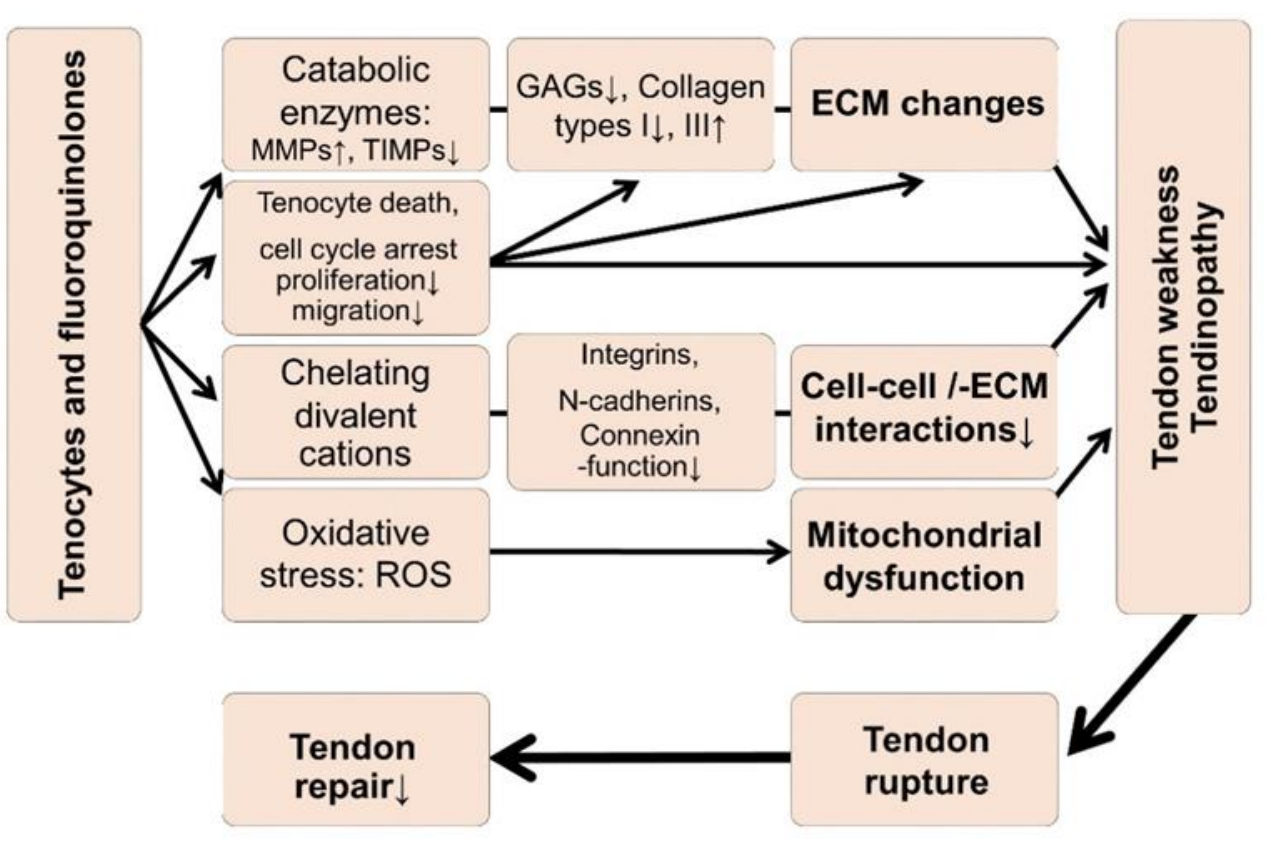

Figure 1. Hypotheses regarding tendinopathy and tendon rupture induced by fluoroquinolones. ECM: Extracellular tendon matrix, MMP: Matrix metalloproteinases, ROS: Reactive oxygen species, TIMP: Tissue inhibitor of metalloproteinases. The graph refers to [15-17,19-23,25-28,50].

Table 1. Serum/plasma concentration in normal patients $(\mathrm{CN})$ in comparison to mean concentrations in uremic patients $(\mathrm{CU})$ and highest concentrations (CM).

\begin{tabular}{ccccccc}
\hline & MW $(\mathbf{g} / \mathbf{m o l})$ & $\mathbf{C}_{\mathbf{N}}$ & $\mathbf{C}_{\mathbf{U}}$ & $\mathbf{C}_{\mathbf{M}}$ & Unit & Reference \\
\hline Quinolinic acid & 167 & 0.1 & 1.5 & 3.3 & $\mathrm{mg} / \mathrm{L}$ & {$[37]$} \\
\hline Phenylacetic acid & 136 & $<1.4$ & 467.2 & 474.6 & $\mathrm{mg} / \mathrm{L}$ & {$[46]$} \\
\hline Ciprofloxacin & 331 & 1.35 to 4.21 & 3.7 & 7.6 & $\mathrm{mg} / \mathrm{L}$ & {$[51-53]$} \\
\hline
\end{tabular}

\subsection{Effects of Ciprofloxacin and Uremic Toxins on Tenocyte Metabolic Activity}

$\mathrm{CPX}$, when administered at higher concentrations (100 mg/L), significantly suppressed tenocyte metabolic activity after short-term exposure ( 8 h; Supplementary Figure S1) and, in addition, after prolonged exposure $(72 \mathrm{~h}$ ) at therapeutic concentrations (Figure 2$)$. PAA significantly reduced tenocyte metabolic activity only after prolonged exposure $(72 \mathrm{~h})$ either to very high doses $(10 \mathrm{mM})$ or when combined with CPX (already with the lowest tested concentration of $3.5 \mathrm{mM}$; Figure 2). However, the suppressive effect of the combined treatment (PAA + CPX) did not significantly differ from that induced by CPX alone.

QA treatment led to no significant cytotoxic effect on cultured tenocytes after $72 \mathrm{~h}$, even at the highest concentration tested $(50 \mathrm{mg} / \mathrm{L})$. The combinations of CPX and QA did not cause greater cytotoxicity than incubation with CPX alone (Figure 2). 

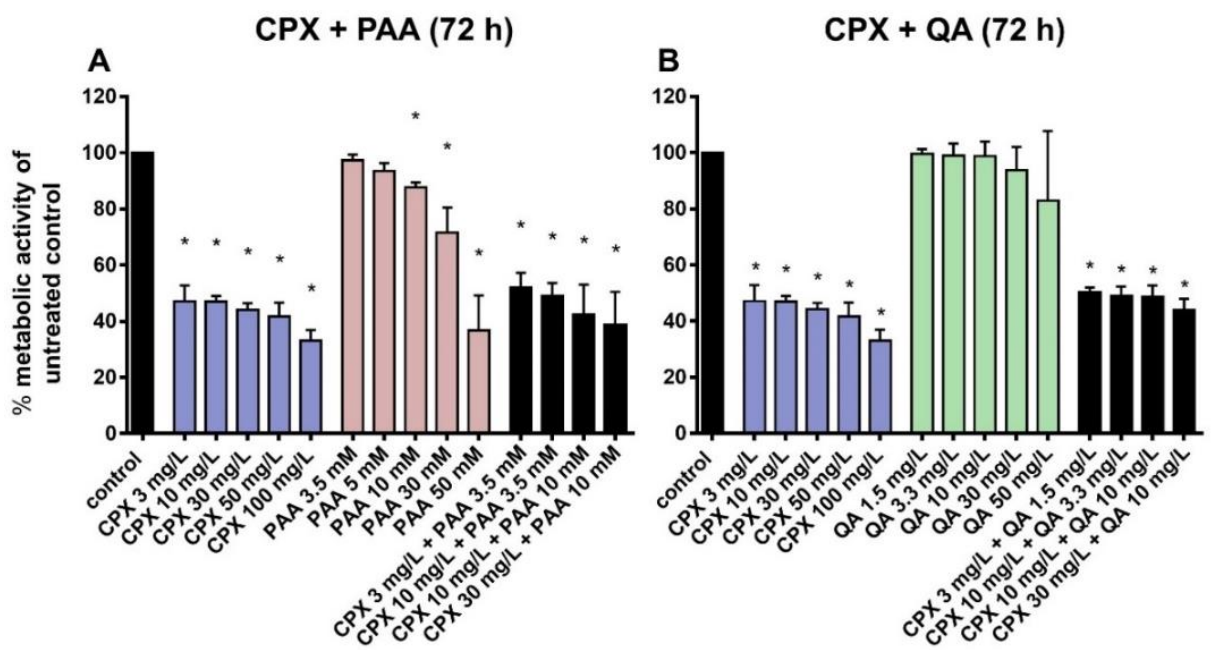

Figure 2. Metabolic activity after $72 \mathrm{~h}$ preincubation with CPX (A,B), PAA (A), QA (B) alone, and combinations of CPX and PAA (A) and CPX and QA (B). The effects of phenylacetic acid (PAA) and quinolinic acid (QA) alone or in combination with ciprofloxacin (CPX) on tenocyte metabolic activity were detected by measuring reduction of alamarBlue after $72 \mathrm{~h}$ of incubation. Results are expressed as a percentage of the activity observed in untreated controls. Bars show the mean \pm standard deviation (SD) obtained from four independent experiments with tenocytes from different patients. ${ }^{*} p \leq 0.05$ compared to control.

\subsection{Tenocyte Survival}

In addition to measuring metabolic activity in response to CPX and uremic toxins, viability staining was performed to visualize viable and dead cells and to calculate their numbers after $72 \mathrm{~h}$ of exposure. The mean percentages of dead cells were below $20 \%$ in all treatment courses. There was only a tendency of increasing numbers of dead cells in response to CPX alone detectable. However, when administered at higher concentrations $(10 \mathrm{mM})$, PAA elevated the number of dead cells significantly. Light microscopy observation revealed some cell clusters and cell loss in cultures treated with PAA combined with CPX (Supplementary Figure S2). In combination with $3 \mathrm{mg} / \mathrm{L} \mathrm{CPX}$, after treatment with $3.5 \mathrm{mM}$ PAA, a significant increase in the number of dead cells was already detectable. QA had no significant suppressive effect on tenocyte survival in the absence of CPX, but the combination of $3.3 \mathrm{mg} / \mathrm{L}$ QA with $10 \mathrm{mg} / \mathrm{L} \mathrm{CPX} \mathrm{significantly} \mathrm{increased} \mathrm{the} \mathrm{amount} \mathrm{of} \mathrm{cell} \mathrm{death} \mathrm{(Figures} 3$ and 4A-C).
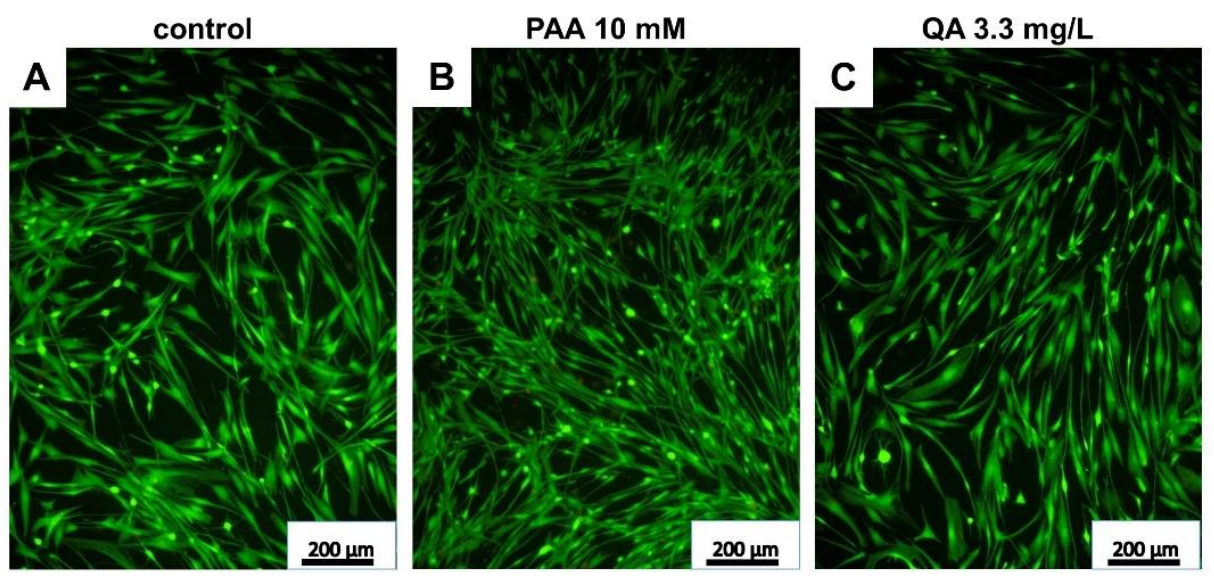

Figure 3. Cont. 


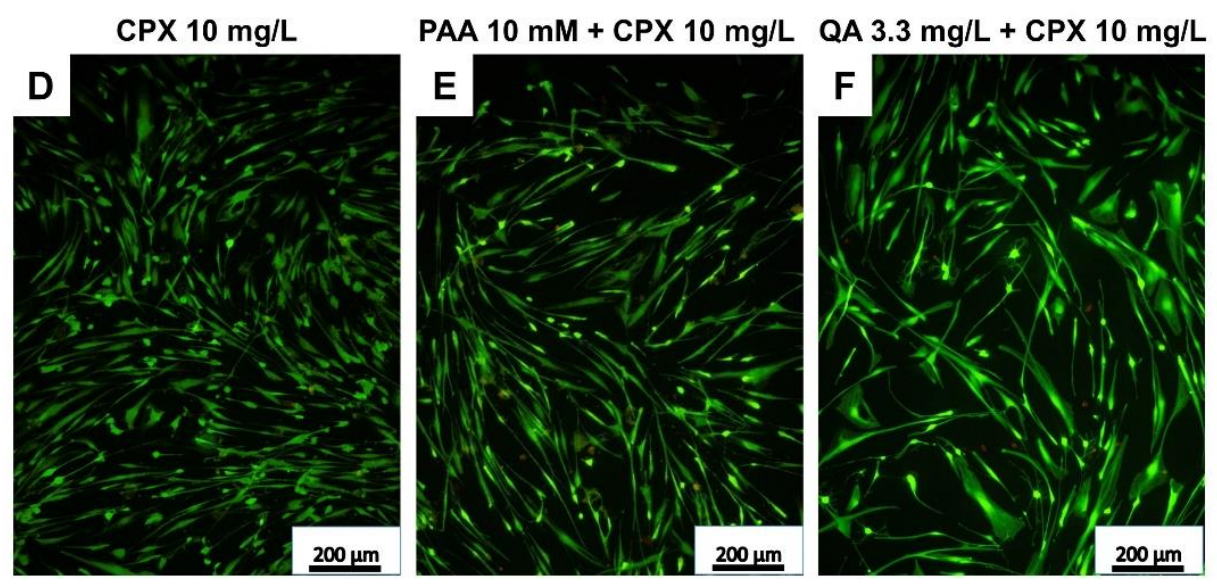

Figure 3. Live/dead staining of human tenocytes after treatment with PAA, QA, CPX, alone or in combination with CPX, for $72 \mathrm{~h}$. Representative images are shown. (A) Untreated control, (B) PAA 10 mM, (C) QA 3.3 mg/L, (D) CPX 10 mg/L, (E) PAA 10 mM + 10 mg/L CPX, (F) QA 3.3 mg/L + CPX $10 \mathrm{mg} / \mathrm{L}$. Living cells—green, dead cells—red. Scale bars $=200 \mu \mathrm{m}$.
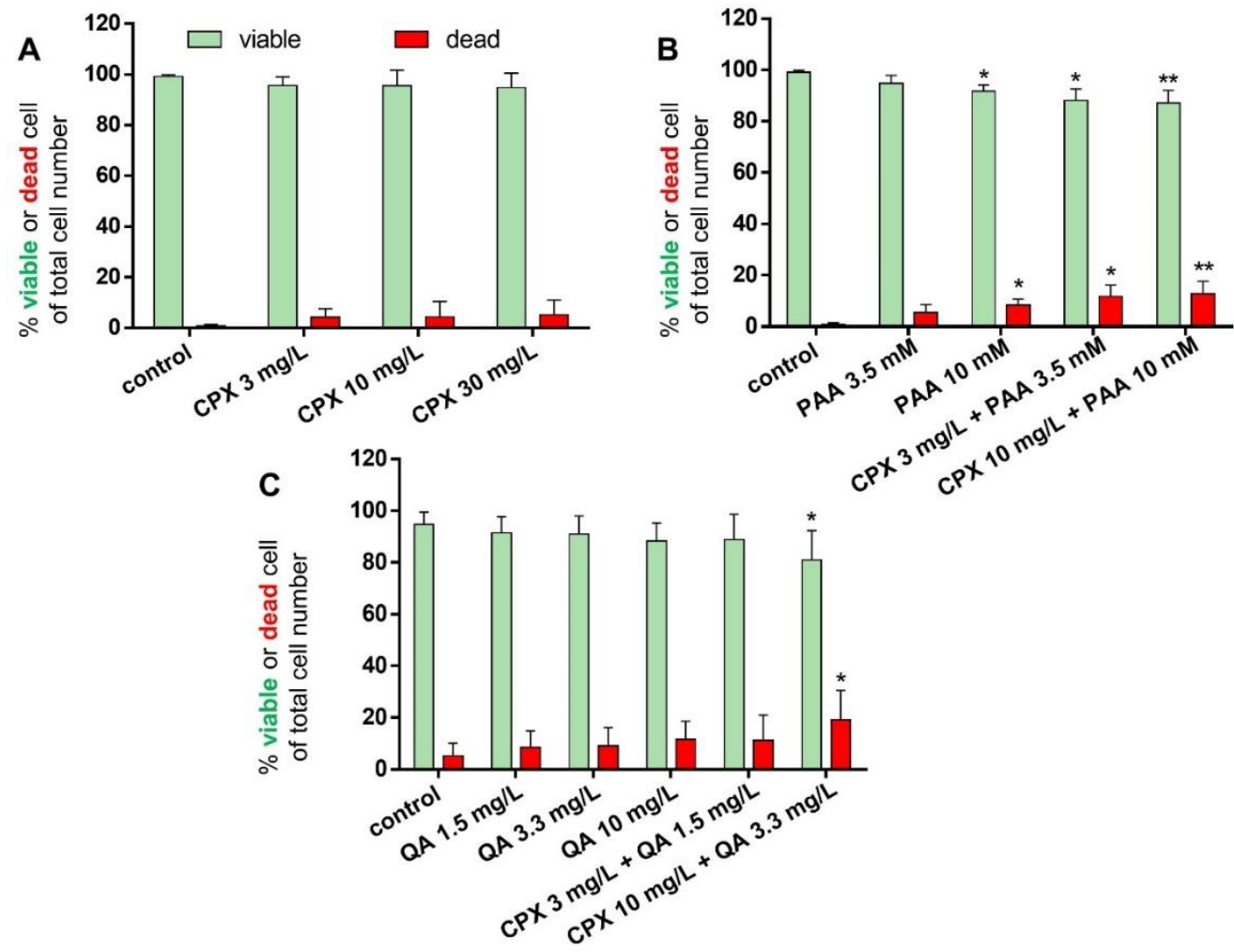

Figure 4. Percentage of surviving and dead tenocytes after $72 \mathrm{~h}$ incubation with CPX alone and with PAA and QA, alone and in combination with CPX. Percentages of viable (green bars) and dead cells (red bars) are shown after incubation with CPX alone for $72 \mathrm{~h}$ (A), PAA alone or combined with CPX (B), and QA alone or combined with CPX (C). Mean values \pm standard deviation are depicted. Results derive from four to seven independent experiments with tenocytes of four to seven different donors. ${ }^{*} p \leq 0.05,{ }^{* *} p \leq 0.01$ compared to control.

\subsection{Effects of Ciprofloxacin and Uremic Toxins on Tenocyte Gene Expression}

CPX, PAA, or QA had no significant effect on the $\beta 1$-integrin (ITGB1) expression. Only the combination of CPX $(3 \mathrm{mg} / \mathrm{L})$ with PAA $(3.5 \mathrm{mM})$ led to a significant suppression of ITGB1 gene expression (Figure 5A). 


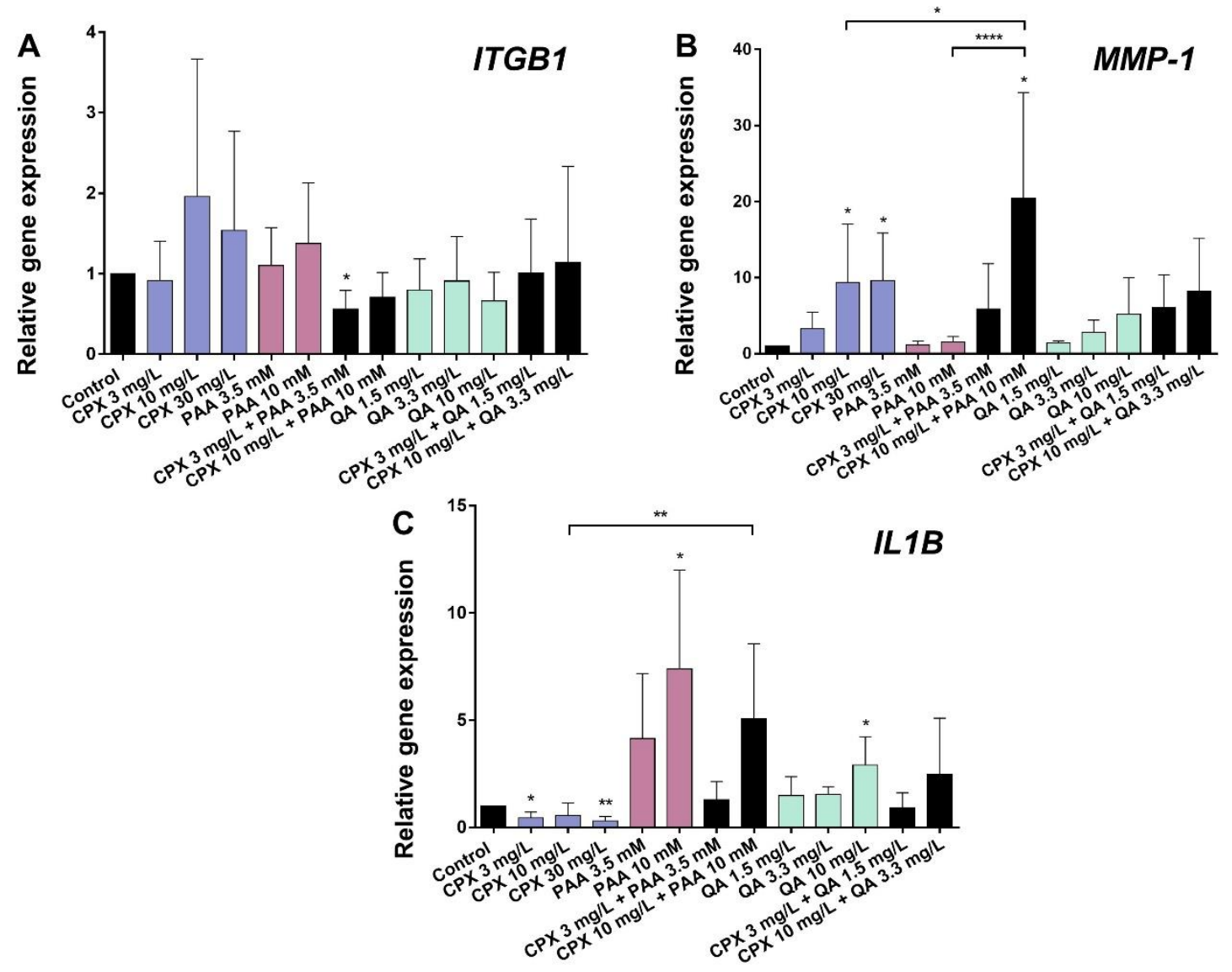

Figure 5. Gene expression of $\beta_{1}$-integrin (ITGB1), MMP-1, and IL-1 $\beta$ (IL1B) in human tenocytes after $72 \mathrm{~h}$ incubation with CPX alone and with PAA and QA, alone and in combination with CPX. (A) ITGB1, (B) MMP-1, and (C) IL1B. Gene expression was normalized using the reference-gene hypoxanthine phosphoribosyltransferase (HPRT) and compared to the untreated control. Bars show the mean $\pm \mathrm{SD}$ (five to six independent experiments with cells of five to six different donors were included). ${ }^{*} p \leq 0.05$, ** $p \leq 0.01,{ }^{* * * *} p \leq 0.001$ compared to control.

The MMP-1 mRNA levels were significantly increased by CPX (10 and $30 \mathrm{mg} / \mathrm{L})$. This effect became more pronounced in the form of a synergism following exposure to a combination of $\mathrm{CPX}$ and PAA $(10 \mathrm{mg} / \mathrm{L}$ and $10 \mathrm{mM})$. QA and its tested combinations with CPX did not influence MMP-1 mRNA levels significantly (Figure 5B).

Gene expression of the pro-inflammatory cytokine IL1B was reduced by CPX after $72 \mathrm{~h}$ compared with the untreated controls. By contrast, PAA and QA significantly up-regulated IL1BmRNA levels at the highest concentrations tested (10 mM PAA and $10 \mathrm{mg} / \mathrm{L} \mathrm{QA})$. Co-stimulation of the cells with $10 \mathrm{mM}$ PAA and $10 \mathrm{mg} / \mathrm{L} \mathrm{CPX} \mathrm{led} \mathrm{to} \mathrm{a} \mathrm{significantly} \mathrm{higher} \mathrm{IL1B} \mathrm{mRNA} \mathrm{expression} \mathrm{than} \mathrm{the} \mathrm{stimulation}$ with CPX alone at the same concentration (Figure 5C).

\subsection{Effects of Ciprofloxacin and Uremic Toxins on Tenocyte Collagen Synthesis, Cytoskeleton, and MMP-1}

Protein levels of intra- and extracellular type I collagen, visualized by immunolabeling of tenocytes cultured on cover slips and treated with CPX, decreased in response to high CPX doses (10 and $30 \mathrm{mg} / \mathrm{L}$ ), whereas PAA and QA—even in combination with CPX—did not affect collagen type I synthesis (Figure 6; Figure 7). However, the suppressive effect of CPX on tenocyte collagen synthesis visualized by immunolabeling did not reach the significance level, but Western blot analysis revealed a significant suppression of collagen type I synthesis in tenocytes exposed to $30 \mathrm{mg} / \mathrm{L} \mathrm{CPX}$ for $72 \mathrm{~h}$ (Figure 8). 

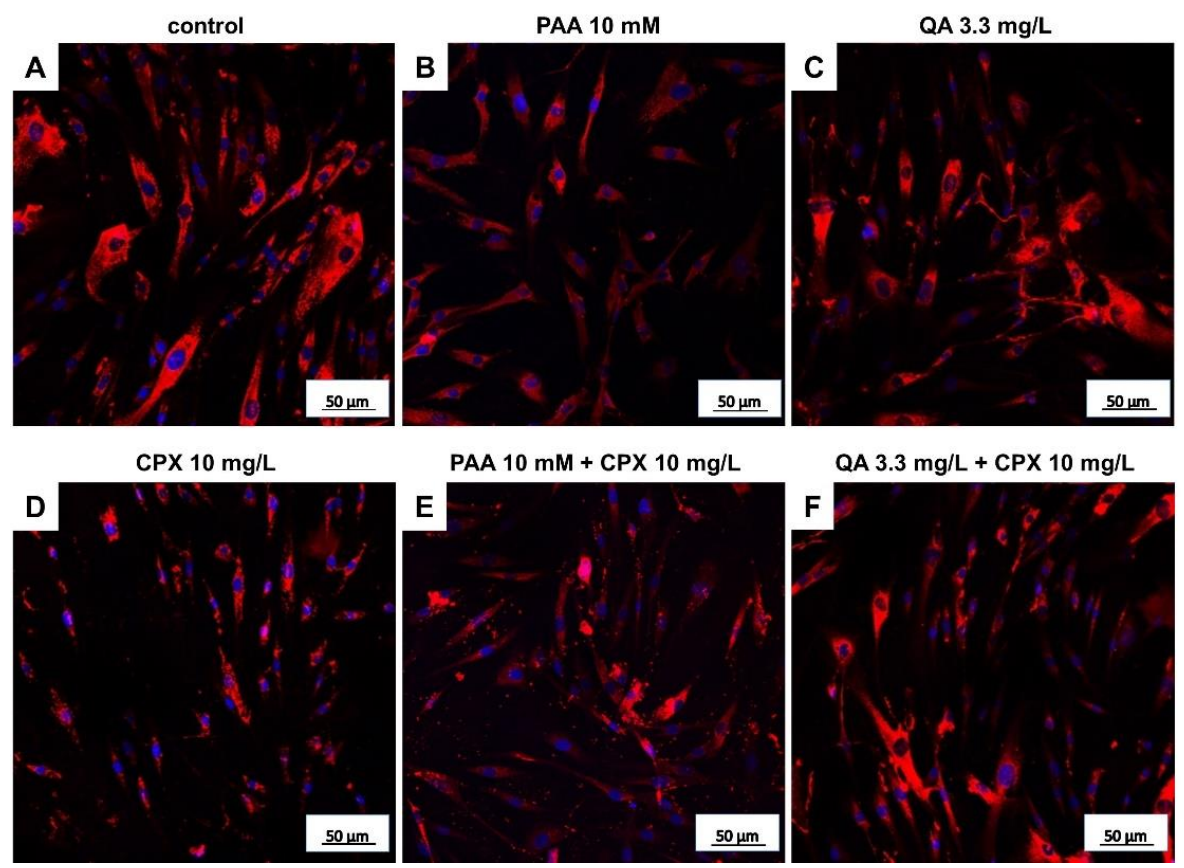

PAA $10 \mathrm{mM}+\mathrm{CPX} 10 \mathrm{mg} / \mathrm{L}$

QA $3.3 \mathrm{mg} / \mathrm{L}+\mathrm{CPX} 10 \mathrm{mg} / \mathrm{L}$
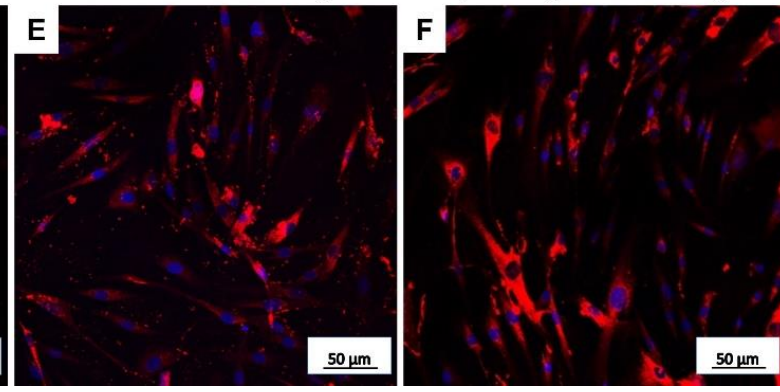

Figure 6. Tenocyte type I collagen expression after $72 \mathrm{~h}$ in response to stimulation with CPX alone and with PAA and QA, alone and in combination with CPX. Representative images of collagen type I immunolabeling (red) are shown. Cell nuclei are counterstained in blue using 4',6'-diamidino-2-phenylindol (DAPI). (A) Untreated control, (B) PAA $10 \mathrm{mM}$, (C) QA $3.3 \mathrm{mg} / \mathrm{L}$, (D) CPX $10 \mathrm{mg} / \mathrm{L}$, (E) PAA $10 \mathrm{mM}+10 \mathrm{mg} / \mathrm{L} \mathrm{CPX,} \mathrm{(F)} \mathrm{QA} 3.3 \mathrm{mg} / \mathrm{L}+$ CPX $10 \mathrm{mg} / \mathrm{L}$. Scale bars $=50 \mu \mathrm{m}$.

\section{type I collagen}
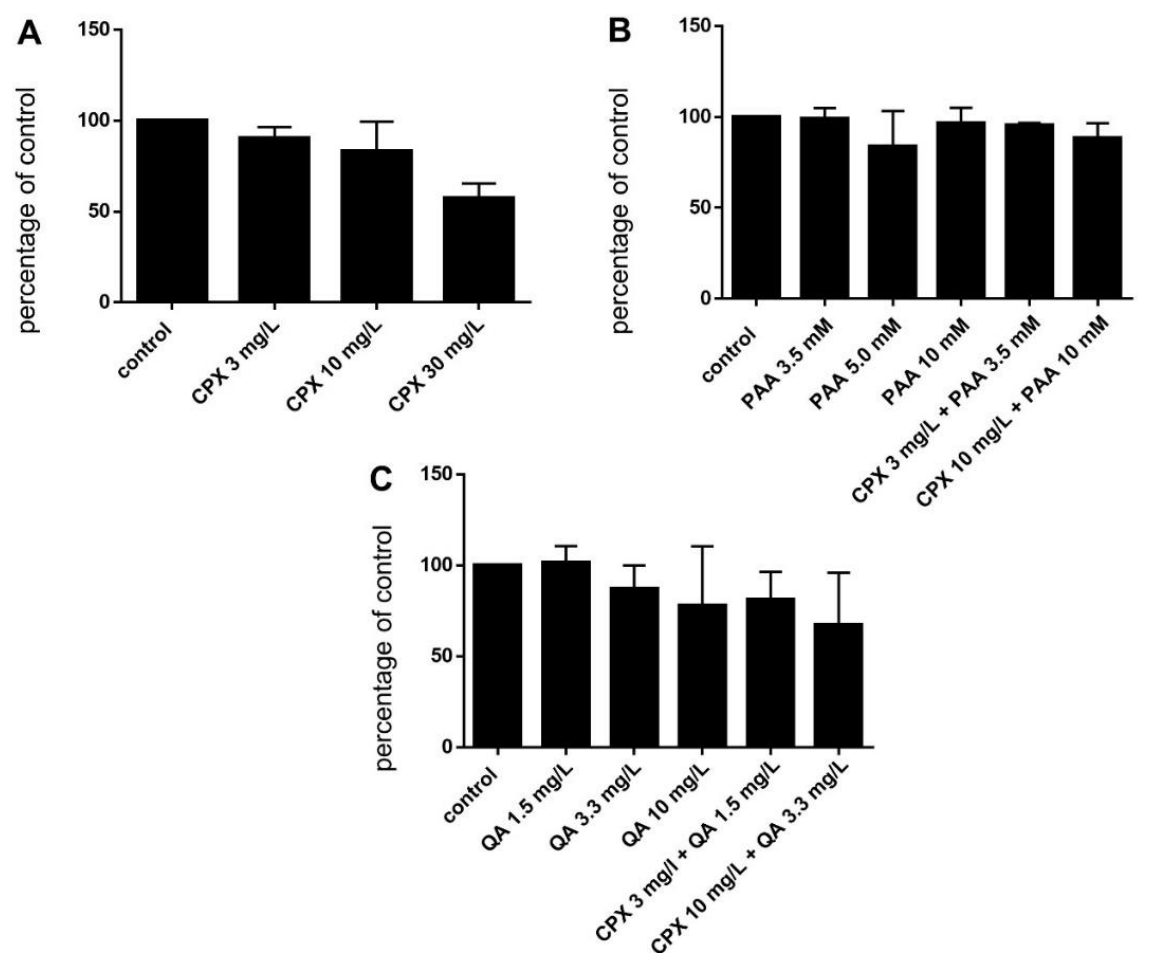

Figure 7. Tenocyte type I collagen expression after $72 \mathrm{~h}$ in response to stimulation with CPX alone and with PAA and QA, alone and in combination with CPX. (A) CPX, (B) PAA combined with CPX, (C) QA combined with CPX. Fluorescence intensities were analyzed using ImageJ. Bars show the mean \pm SD. 


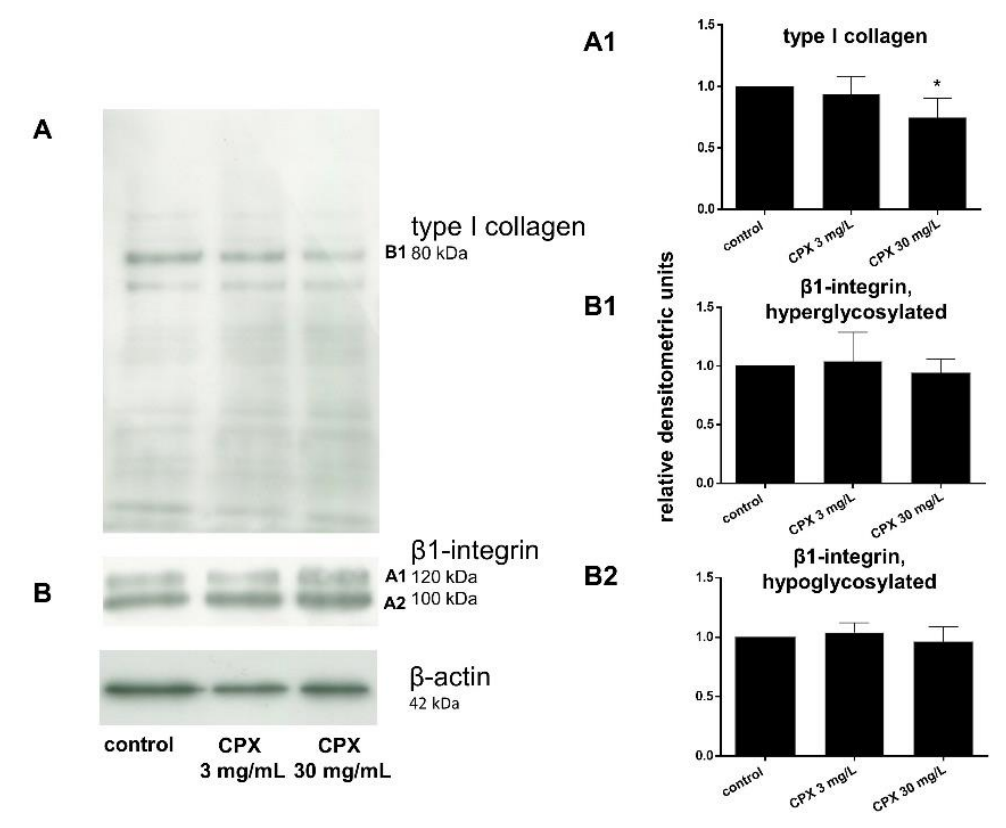

Figure 8. Type I collagen and $\beta 1$-integrin expression of tenocytes treated with ciprofloxacin as shown by Western blot analysis and densitometric evaluation after $72 \mathrm{~h}$. (A) Representative Western blot of type I collagen expression, (A1) densitometric evaluation of the type I collagen Western blots. (B) Representative Western blot of $\beta 1$-integrin expression. The two visible bands (hyperglycosylated and hypoglycosylated forms $(\mathbf{B 1}, \mathbf{A 2}))$ of the $\beta 1$-integrin were densitometrically evaluated in the Western blots performed for $\beta 1$-integrin detection. Collagen type I, $n=4$ : $\beta 1$-integrin, $n=5$ : Collagen type I. Independent experiments were performed with cells from different donors. ${ }^{*} p \leq 0.05$ compared to control.

All tenocytes, irrespectively whether treated or not, formed multiple intracellular F-actin bundles (stress fibers) connected to the cells' focal adhesion sites. The organization of the F-actin cytoskeleton and amount of stress fibers in tenocytes did not show major differences in response to the various treatment courses. However, cells exposed to PAA appeared to have a more slender morphology (Supplementary Figure S3).

The effect of CPX on $\beta 1$-integrin was investigated on the protein level by Western blot analysis and even a high concentration of $30 \mathrm{mg} / \mathrm{L}$ did not affect tenocyte $\beta 1$-integrin expression.

MMP-1 was barely detectable intracellularly at the protein level; hence, no effect could be demonstrated by means of immunolabeling.

\section{Discussion}

Based on an increasing number of case reports, hemodialysis has been suggested to be a risk factor for tendon ruptures [32,33,35,54-61]. However, published reports concerning the direct impact of uremic toxins and a possible additive effect with CPX on tendon-derived cells were not available. Hence, the present in vitro study was performed to investigate the impact of two selected uremic toxins (PAA and QA) alone or combined with CPX on tenocytes. For selecting a reasonable concentration for stimulating the tenocytes in this study the serum concentrations have been considered. The peak serum concentrations of CPX, given orally or intravenously, range from 0.5 to $10 \mu \mathrm{g} / \mathrm{mL}$ [62] (Table 1). In the present study, higher concentrations were also tested, since the levels might be locally and systemically elevated in renal insufficiency patients. The plasma concentration of PAA in normal individuals is $<1.4 \mathrm{mg} / \mathrm{L}$, while, during uremia, it can increase to $467.2 \mathrm{mg} / \mathrm{L}$ [46] (Table 1). QA normally has a serum concentration of $0.1 \mathrm{mg} / \mathrm{L}$, but can increase during uremia to $1.5 \mathrm{mg} / \mathrm{L}$ and can reach a maximum of $3.3 \mathrm{mg} / \mathrm{L}$ [38] (Table 1). PAA is partly (30\%) protein-bound and, hence, difficult to eliminate by hemodialysis [39]. It is an inhibitor of $\mathrm{Ca}^{++}$-ATPase [46]. QA is a degradation product of the essential 
amino acid tryptophan, which is cleaved at higher rates under the conditions of renal insufficiency and likely contributes to immunosuppression, cardiovascular complications and neurotoxic side effects [38,48,63-65]. Tenocytes harvested from 14 healthy and young donors (mean age 34.9 years, 50\% male) of hamstring tendons were tested in the present study for the effect of PAA, QA, and CPX. It has to be considered that, possibly, tenocytes from Achilles tendons, the tendon most often ruptured in response to $\mathrm{CPX}$, might be more sensitive. In addition, tenocytes from patients with renal insufficiency and older ages might differ in their response, since both conditions predispose tendon tissue to rupture and, hence, the tendon degeneration preceding it $[12,30]$. In the present study no donor dependency was observed probably due to the small donor collective included.

When using these cells from healthy tendons, after $72 \mathrm{~h}$ at all concentrations tested, CPX exerted a significant suppressive effect on tenocyte metabolic activity. PAA impaired it at the same time only at higher concentrations, with no detected additional enhancement by CPX in co-treated cells, while QA had no significant effect. The measured impaired rates of metabolic activity could result from an inhibition of cell proliferation, reduced cellular activity or from increased rates of cell death, which have already been described for CPX $[19,66]$. Hence, the rate of dead cells was determined.

The rate of dead cells in CPX-treated tenocytes was higher (around 5\%) than in the controls with only $0.8 \%$ of dead cells in the present study but remained low at all. In accordance with the above-mentioned suppression of tenocyte metabolism, PAA significantly induced tenocyte death. Interestingly, QA at its highest concentration, when combined with CPX, increased the rate of dying cells. Further studies should examine whether apoptosis or necrosis occurs, and which cell death pathways are most likely to be activated. Since tendon is a hypocellular tissue and few tenocytes have to regulate ECM de novo synthesis and remodeling the loss of few tenocytes might substantially impair tendon's adaptability to tension and strength.

Tendon ruptures as observed in response to CPX treatment or renal insufficiency could be the result of a loss of tendon stability due to dysbalanced ECM remodeling or cell-ECM interaction. Type I collagen, the main tendon ECM protein, is a ligand for integrin receptors expressed on the tenocyte surface, particularly those possessing the $\beta 1$-integrin chain. $\beta 1$-integrins mediate the interaction between tenocytes and their surrounding ECM as a precondition for tendon integrity, but their function is divalent cation dependent [24]. Although, the suppressive effect of CPX (3-160 mg/L) on integrins has been shown in finger tendon-derived tenocytes and chondrocytes by others $[24,66]$, to be explained by divalent cation deprivation mediated by the chelating properties of CPX, it could not be shown at the gene and protein expression level under the experimental setting of the present study. However, we did not address integrin activation in the present study. Integrins can be activated by inside-out signaling [67]. Under this condition cytoskeletal changes lead to integrin clustering in the cell membrane or conformational changes which influence their ligand binding affinity. The modulation of integrin glycosylation has also been implicated in integrin activation $[67,68]$. Hence, we checked the hyperglycosylated and less glycosylated forms of integrins separately in Western blot analysis, but we found, in agreement with the gene expression data, no regulation by CPX.

The effect of CPX on these important aspects is unknown; however, another class of quinolone compounds has been described as integrin antagonists [69] and CPX inhibited chondrocyte adhesion on collagen indicating disturbed integrin function [24].

The number of integrins as a correlate of gene and protein expression might determine function, such as enhanced cell adhesion in response to larger integrin clusters exposed on the cell membrane. Surprisingly, the gene expression of $\beta 1$-integrin (ITGB1) was suppressed by a combination of CPX and PAA in the present study. This additive effect of CPX and PAA on $\beta 1$-integrin gene expression is of interest since both agents alone had no effect. We can conclude that the same target of the same or crossing signaling pathways might be affected by CPX and PAA. One could study the $\mathrm{Ca}^{++}$ homeostasis, since PAA affects $\mathrm{Ca}^{++}$ATPase [46], as mentioned above, and CPX can act as a chelator. F-actin visualization demonstrated stress fibers but revealed no differences of F-actin cytoskeleton between the treatment courses. Stress fibers are bundled at focal adhesion sites where usually integrin 
clusters are localized. Hence, the staining could indirectly visualize integrin-associated focal adhesion sites. Integrins are important mediators of tenocyte/ECM homeostasis [67,70].

To adapt their ECM to novel conditions, cells release MMPs such as MMP-1 [71]. Therefore, the expression of MMP-1 expression, which is the most important MMP in tendons and is capable of cleaving the mean component of the tendon ECM, type I collagen, was investigated.

$M M P-1$ gene expression was induced by CPX, an observation supported by other studies $[23,66]$. However, in the study of Corps et al. [72], $M M P-1$ gene expression was only substantially induced by poststimulation with IL-1 $\beta$. This inductive effect of CPX was enhanced in the present study by a combination with PAA, but not by co-stimulation with QA. Nevertheless, distinct MMPs are intimately regulated by their activation through cleavage of proenzymes and by local inhibition by specific TIMPs [71]. This study is limited by the fact that the MMP activation and the balance between TIMPs and activated MMPs under the influence of PAA and QA was not addressed. These factors should be further investigated in cell culture supernatants in future.

The direct effect of CPX, PAA, and QA on the main ECM component type I collagen was investigated here, and neither PAA nor QA, either alone or in combination with CPX, was found to have a significant suppressive effect on its protein expression, as shown by image analysis, but a suppressive trend was detectable in response to $30 \mathrm{mg} / \mathrm{mL}$ CPX. Since cells were permeabilized for immunolabeling, the intracellular collagen type I precursor was shown here by the antibody localized mainly in the rough endoplasmatic reticulum (rER) region of the cells. The collagen released by the cells could not be visualized by this technique. As an important limitation of our present study, we did not quantify the release of collagen type I in the tenocyte culture supernatants. Western blot analysis revealed for the same treatment by CPX a significant collagen type I suppression. This observation of limited effects on tenocyte collagen expression is supported by the study of Chang et al., (2012), who found no suppression of type I collagen by CPX but an increase in type III collagen. Menon et al. detected no effect neither on type I nor III collagen mRNA and protein expressions [22]. This collagen type, which is known to increase in tendons during repair and remodeling [73], was not tested here. The presence of substantial collagen type I remodeling has been abrogated in the core of mature healthy tendons, as shown by two important studies of Heinemeier et al., [74,75]. However, the authors hypothesized that collagen turnover precedes the onset of tendinopathy [75].

IL-1 $\beta$ is a typical proinflammatory cytokine known to play a role in tendon disorders such as tendinopathy [76]. Interestingly, IL-1 $\beta$ (IL1B) gene expression was reduced by CPX in the present study. Despite the fact that there exists no comparable data in published studies; results obtained by others indicate an antagonism between CPX and IL-1 $\beta$, for example, by reducing IL- $1 \beta$ induced PGE2 release by CPX [77]. In contrast to CPX, $10 \mathrm{mg} / \mathrm{L}$ PAA significantly induced gene transcription of this important proinflammatory cytokine, even in the presence of $\mathrm{CPX}$, suggesting that it might contribute to the development of tendinopathy. The present study is limited by testing only two uremic toxins separately in a 2D model, since multiple interactions might occur among many uremic compounds accumulated in hemodialysis patients, possibly being involved in predisposing their tendons to rupture.

\section{Materials and Methods}

\subsection{Preparation of Agents Used for Tenocyte Stimulation}

The quinolone ciprofloxacin (CPX) was obtained from commercially available solutions for intravenous infusion (CPX-Infusionslösung, 200 mg/100 mL (Fresenius Kabi, Bad Homburg vor der Höhe, Germany). The uremic toxins phenylacetic acid (PAA) and quinolinic acid (QA) were purchased from Sigma-Aldrich (Taufkirchen, Germany). Concentrated stock solutions were prepared. PAA was diluted in ethanol (stock solution, $500 \mathrm{mM}, \mathrm{pH} 7.0$ ) with sonication and further diluted to $100 \mathrm{mM}$ in distilled water ( $\mathrm{pH} 7.0$, sterile filtered). A sterile (pyrogen-free) $\mathrm{NaCl}$ solution $(0.9 \% w / v)$ was used as 
a solvent for QA (500 mM and $100 \mathrm{mM}$ stock solutions, sterile filtered). The $\mathrm{pH}$ was adjusted to 7.0. Stock solutions were stored at $-20^{\circ} \mathrm{C}$. All further dilutions were done with cell culture medium.

\subsection{Tenocyte Isolation and Culture}

Human primary tenocytes were isolated from the midsubstance of 14 hamstring tendons (Musculus (M). semitendinosus, $M$. semimembranosus, $M$. gracilis tendons) of healthy middle-aged donors (average age 34.9 years; 7 females, 7 males). This study was approved by the Charite review board (EA4-033-08, 22 May 2008) for experiments with human-derived tissues. The surrounding connective tissue and peritendineum of the tendons was carefully removed before culturing $2 \times 5 \mathrm{~mm}$ tendon explants in a growth medium for several days. After 7-14 days, tenocytes continuously emigrated from these explants and adhered to petri dishes. When cell density approached confluence, these cells were detached using 0.05\% trypsin/1.0 mM EDTA (Biochrom, Berlin, Germany) and further expanded in T75 flasks. Cells were cultured at $37^{\circ} \mathrm{C}$ in a humidified atmosphere with $5 \% \mathrm{CO}_{2}$. The growth medium was composed of Ham's F-12/Dulbecco's modified Eagle's medium (50/50, Biochrom) containing 10\% fetal calf serum (FCS, Biochrom), $25 \mu \mathrm{g} / \mathrm{mL}$ ascorbic acid [Sigma-Aldrich], $50 \mathrm{IU} / \mathrm{mL}$ streptomycin, $50 \mathrm{IU} / \mathrm{mL}$ penicillin, $2.5 \mu \mathrm{g} / \mathrm{mL}$ amphotericin B, essential amino acids, L-glutamine (all: Biochrom), and it was changed every three days. For the experiments, tenocytes were cultured at $15,625 \mathrm{cell} / \mathrm{s} / \mathrm{cm}^{2}$ in 6-, 12-, or 96-well plates (Sarstedt AG, Nümbrecht, Germany) in the growth medium with 1\% FCS. To achieve enough cells for all experiments tenocytes were expanded at least until passage (P) 4-6. Most of the experiments were performed with cells of P4. We confirmed the expression of tendon-associated proteins such as scleraxis, mohawk, tenomodulin, tenascin C, decorin, and CD90, typical for differentiated tenocytes in representative samples (Supplementary Figure S4).

\subsection{Tenocyte Stimulation with Ciprofloxacin and Uremic Toxins}

To monitor the effects of $\mathrm{CPX}$ and uremic toxins, tenocytes were stimulated with the respective agents, alone or in combination. Tenocytes were serum-starved in a growth medium containing $1 \%$ FCS for $24 \mathrm{~h}$ before being incubated with the agents at different concentrations (CPX-3, 10, 30, 50, and $100 \mathrm{mg} / \mathrm{L}$; PAA-3.5, 5, 10, 30 and $50 \mathrm{mM}$; QA-1.5, 3.3, 10, 50 and $100 \mathrm{mg} / \mathrm{L}$ ). Since the solvent did not influence the results, as shown by preliminary experiments, it was omitted later in the control experiments. Hence, the control group was treated with a serum-reduced medium in the absence of stimulating agents.

\subsection{AlamarBlue Assay}

The cytotoxicity of the agents was determined by analyzing human tenocytes for their metabolic activity in response to treatment with CPX and uremic toxins. Tenocytes were cultured in 96-well plates at 15,625 cells/ $\mathrm{cm}^{2}$ (Sarstedt AG, Nümbrecht, Germany). A 10\% alamarBlue assay reagent (Life Technologies, Carlsbad, CA, USA) was added to the culture medium either immediately together with the stimulation agents (CPX, PAA, QA) or after the cells had been incubated with these agents for $72 \mathrm{~h}$. The effect on metabolic activity in response to the different treatments was compared to the untreated control (culture medium with cells but without test reagent), which represented $100 \%$ metabolic activity. Induction of cell death was performed using sodium dodecyl sulfate (SDS; Carl Roth $\mathrm{GmbH}$, Karlsruhe, Germany) as a negative (toxic) control at a concentration of $1 \mathrm{mM}$. The experiments were carried out independently using tenocytes of four different donors. The readout $(2,4,6,8$, and $24 \mathrm{~h}$ ) was performed via absorbance measurement at a wavelength of $570 \mathrm{~nm}$ and at a reference wavelength of $600 \mathrm{~nm}$ using a Genios microplate reader (Tecan Group AG, Männedorf, Switzerland).

\subsection{Vitality Assay}

Tenocytes seeded on Poly-L-lysin (Biochrom)-coated cover slides and stimulated with the agents for $72 \mathrm{~h}$ were incubated in a mixture of $5 \mu \mathrm{L} / \mathrm{mL}$ fluorescein diacetate (Sigma-Aldrich, $3 \mathrm{mg} / \mathrm{mL}$ dissolved in acetone (stock solution)) and $1 \mu \mathrm{g} / \mathrm{mL}$ ethidium bromide (Carl-Roth, Karlsruhe, Germany) 
diluted in $1 \mathrm{~mL}$ phosphate-buffered saline (PBS) for $10 \mathrm{~min}$. The green (vital) or red (dead) cell fluorescence was visualized using fluorescence microscopy (Axioskop 40, Carl Zeiss, Jena, Germany) using a digital camera (Color View II, Olympus, Shinjuku, Japan). Three microscopic fields of each treatment group in each independent experiment were evaluated using Image for vital and dead cells.

\subsection{Gene Expression Analysis}

Real-time detection polymerase chain reaction (RTD-PCR) analysis was performed to obtain semiquantitative gene expression data for $\beta 1$-integrin (ITG1), MMP-1, and IL-1 $\beta$ (IL1B) versus hypoxanthine phosphoribosyltransferase (HPRT) as a reference gene. Tenocytes were cultured at $15,625 \mathrm{cells} / \mathrm{cm}^{2}$ in 6-well plates for $24 \mathrm{~h}$ before stimulation. The cells were then rinsed with PBS, serum-starved (growth medium with $1 \%$ FCS) for $1 \mathrm{~h}$, and stimulated for $72 \mathrm{~h}$ with the agents. The tenocytes' total RNA was isolated using a Qiagen RNA isolation mini kit (Qiagen, Hilden, Germany), and the RNA quantity and purity were evaluated using the RNA 6000 Nano assay (Agilent Technologies, Santa Clara, CA, USA). Reverse transcription was performed using the Quanti Tect Reverse Transcription Kit and equal amounts of RNA (500 ng) according to the manufacturer's instructions (Qiagen). Aliquots of $1 \mu \mathrm{L} \mathrm{cDNA}(16.7 \mathrm{ng}$ ) of each sample were amplified using RTD-PCR in a $20 \mu \mathrm{L}$ reaction using the TaqMan Gene Expression Assay (Applied Biosystems (ABI), Foster City, CA, USA) and specific primer pairs (see Table 2, ABI) using an Opticon 1 Real-Time-Cycler (Opticon ${ }^{\mathrm{TM}}$ RTD-PCR, Biorad, Hercules, CA, USA). The following conditions of amplification were chosen-2 min at $50{ }^{\circ} \mathrm{C}, 10 \mathrm{~min}$ at $95^{\circ} \mathrm{C}$ (for Uracil-N-glycosylase activation and denaturation to remove carry overs), and then, for 40 cycles, $15 \mathrm{~s}$ at $95^{\circ} \mathrm{C}, 60 \mathrm{~s}$ at $60^{\circ} \mathrm{C}$, and then $6{ }^{\circ} \mathrm{C}$ cooling. Relative gene expression levels were normalized and calculated using the $2^{-\Delta \mathrm{CT}}$ method [78].

Table 2. Primers used for RTD PCR in the present study (purchased via ABI, USA).

\begin{tabular}{ccc}
\hline Gene Name & Amplicon Size & Assay ID \\
\hline HPRT1 & $100 \mathrm{bp}$ & Hs99999909_m1 \\
\hline IL1B & $94 \mathrm{bp}$ & Hs00174097_m1 \\
\hline ITGB1 & $75 \mathrm{bp}$ & Hs00559595_m1 \\
\hline MMP-1 & $133 \mathrm{bp}$ & Hs00233958_m1 \\
\hline
\end{tabular}

\subsection{Immunofluorescence Microscopical Analysis}

Tenocytes were cultured on cover slips for $24 \mathrm{~h}$, serum-starved for $1 \mathrm{~h}$, and treated for $72 \mathrm{~h}$ with the different agents before fixing in a $4 \%$ paraformaldehyde ready-to-use solution (PFA, Carl Roth, Germany) for $15 \mathrm{~min}$. Tenocytes were washed with Tris-buffered saline (TBS-0.05 M Tris, $0.15 \mathrm{M}$ $\mathrm{NaCl}, \mathrm{pH} 7.6)$ and incubated with protease-free donkey serum (5\%, diluted in TBS and $0.1 \%$ Triton $\mathrm{X}-100$ ) for $20 \mathrm{~min}$ at ambient temperature (RT). Subsequently, cells were rinsed and incubated with the primary antibodies in a humid chamber for $24 \mathrm{~h}$ overnight at $4{ }^{\circ} \mathrm{C}$. The following primary antibodies were used-rabbit anti-human type I collagen (Acris Antibodies, Hiddenhausen, Germany), mouse anti-human MMP-1 (R\&D Systems, Minneapolis, MN, USA), rabbit anti-human mohawk (Biozol, Eching, Germany), scleraxis, decorin (both: Acris Antibodies); mouse anti-human tenascin C (GeneTex Inc. Biozol), CD90 (Miltenyi Biotec, Bergisch Gladbach, Germany); goat anti-human tenomodulin (Santa Cruz Biotechnology, Dallas, TX, USA), as well as mouse and rabbit isotype IG1 antibodies (BD Bioscience, Franklin Lakes, NJ, USA, and Invitrogen, Carlsbad, CA, USA). Tenocytes were subsequently washed three times (each $5 \mathrm{~min}$ ) with TBS before incubation with donkey anti-mouse or -rabbit Alexa-Fluor ${ }^{\circledR} 488$ (Invitrogen), donkey anti-rabbit Alexa-Fluor ${ }^{\circledR} 555$, donkey anti-mouse or -goat cyanine 3-coupled secondary antibodies or Phalloidin-Alexa488 (diluted 1:200 in TBS), and $4^{\prime}, 6^{\prime}$-diamidino-2-phenylindol (DAPI) (Roche Diagnostics, Rotkreuz, Switzerland) for counterstaining cell nuclei, respectively, for $1 \mathrm{~h}$ at RT. Immunolabeled tenocytes were washed three times with TBS, before being mounted using a Fluoromount mounting medium (Southern Biotech, Biozol Diagnostica, 
Eching, Germany) and examined under a fluorescence microscope (Axioskop 40, Carl Zeiss, Jena, Germany). The immunofluorescence images were taken under standardized conditions at 200x magnification. Three images were taken for each staining, and, in each image, four to eight cells were analyzed for fluorescence intensity using the Image software (Rasband, National Institutes of Health, Bethesda, MD, USA). According to the average fluorescence intensity value, the background fluorescence was subtracted.

\subsection{Western Blot Analysis and Densitometric Evaluation}

Type I collagen expression was analyzed using Western blot analysis using $\beta$-actin as the reference protein. Tenocytes were rinsed twice with ice-cold PBS and then incubated with a $0.3 \mathrm{~mL}$ lysis buffer (1 tablet of complete Mini Protease Inhibitor Cocktail [Roche Diagnosticsnd], $100 \mu \mathrm{L} 200 \mathrm{mM}$ 1,4-dithio-DL-threitol (DTT; Carl Roth), $100 \mu \mathrm{L} 0.1$ M ethylene glycol tetra acetic acid (EGTA; Carl Roth), $250 \mu \mathrm{L} 1 \mathrm{M}$ 4-(2-hydroxyethyl)-1 piperazine ethanesulfonic acid (HEPES; Biochrom), $100 \mu \mathrm{L} 0.5 \mathrm{M}$ magnesium chloride ( $\mathrm{MgCl}_{2}$; Sigma-Aldrich), $100 \mu \mathrm{L}$ 10\% Triton X-100 (Sigma-Aldrich), and ultrapure water ad $10 \mathrm{~mL}$ for $5 \mathrm{~min}$. Cell disintegration was achieved by scraping of the adherent cells using cell scrapers (TPP, Trasadingen, Switzerland). The cell lysate was pipetted into $1.5 \mathrm{~mL}$ tubes and centrifuged at $17,000 \times \mathrm{g}$ and $4{ }^{\circ} \mathrm{C}$ for $30 \mathrm{~min}$. The supernatants containing total cell proteins were transferred into novel $1.5 \mathrm{~mL}$ reaction tubes and mixed with $6 \times$ Laemmli buffer $(1 \mathrm{M}$ Tris $\mathrm{HCl} \mathrm{pH} 6.8,4.2 \%$ sodium dodecyl sulfate (SDS), 2.1\% $\beta$-mercaptoethanol (Sigma-Aldrich), bromophenol blue (Serva, Heidelberg, Germany), $7.5 \%$ glycerine (Sigma-Aldrich)) to reach a target volume of $100 \mu \mathrm{L}$ and denaturized by incubation at $95^{\circ} \mathrm{C}$ for $10 \mathrm{~min}$. Protein samples ( $20 \mu \mathrm{L}$ per lane) were separated by SDS polyacrylamide gel electrophoresis (SDS-PAGE) at $80 \mathrm{~V}$ for $30 \mathrm{~min}$ and $120 \mathrm{~V}$ for $60-90 \mathrm{~min}$ using $7.5 \%$ separating and $5 \%$ collecting gels. Ten to $15 \mu \mathrm{L}$ Precision Plus Protein ${ }^{\mathrm{TM}}$ Kaleidoscope Standards (Bio-Rad Laboratories, Munich, Germany) loaded into the first slot served as a protein size reference. A polyvinylidenfluoride (PVDF) membrane (0.45 $\mu \mathrm{m}$ pore size (Merck Millipore, Burlington, MA, USA)) was immersed for $2 \mathrm{~min}$ in 100\% methanol (Merck Millipore, Darmstadt, Germany) for activation before proteins were transferred onto it using $120 \mathrm{~V}$ for $90 \mathrm{~min}$. Thereafter, the PVDF membrane was blocked with blocking buffer (1:9 Roti ${ }^{\circledR}$-Block (Carl Roth) in distilled water) at room temperature (RT) for $2 \mathrm{~h}$ to saturate any unspecific binding sites. The membranes were incubated with the specific primary antibody overnight at $4{ }^{\circ} \mathrm{C}$ (rabbit anti-human collagen type I (Acris Antibodies, Hiddenhausen Germany)) or for $1 \mathrm{~h}$ at RT ( $\beta$-actin, A5441, Sigma-Aldrich). The membranes were then washed once in PBS, two-times with washing buffer (0.5 mL Tween-20 [Sigma-Aldrich] in PBS ad $1.000 \mathrm{~mL})$, and once again with PBS. Incubation with the enzyme-coupled secondary antibodies (goat anti-mouse and goat anti-rabbit (P0447 and P0448), DAKO Cytomation, Hamburg, Germany) was performed for $2 \mathrm{~h}$ at RT. After washing as described above, the chemiluminescence reaction was initiated using horseradish peroxidase substrate peroxide solution (Merck Millipore) and luminol reagent (Merck Millipore). The resultant chemiluminescence was detected using high-performance chemiluminescence films (GE Healthcare Limited, Chalfont St. Giles, UK). Densitometric evaluation of the Western blot analyses was performed using Bio 1D software (Vilber-Luormat, Eberhardzell, Germany).

\subsection{Statistical Analysis}

Statistical analysis was performed using GraphPad Prism 6 software (GraphPad Software Inc., San Diego, CA, USA). Results were normalized versus the non-stimulated control and analyzed using a one sample t-test. ANOVA, followed by a post hoc Bonferroni test, was used to compare different experimental groups. The GRUBBS' test was applied to detect outliers. If applicable, the Kolmogorov-Smirnov and the Shapiro-Wilk tests were used to analyze the data for the presence of a Gaussian distribution. All data were expressed as the mean and standard deviation of the mean (mean $\pm \mathrm{SD}$ ). Differences between experimental groups and controls were considered significant at ${ }^{*} p \leq 0.05,{ }^{* *} p \leq 0.01,{ }^{* * *} p \leq 0.005$ and ${ }^{* * *} p \leq 0.001$. 


\section{Conclusions}

The results of this study could visualize distinct suppressive effects of the two selected uremic toxins, QA and, more pronouncedly, PAA, on tenocytes. PAA suppressed tenocyte metabolic activity and increased the rate of cell death, while QA induced IL1B gene expression at a concentration of $10 \mathrm{mg} / \mathrm{L}$. The results also confirmed some of the previously reported effects of CPX on tenocytes suppressing metabolic activity and at high concentration collagen type I protein as well as induction of MMP-1 gene expression. A possible additive effect with CPX could only be shown for PA, namely, detectable as a suppressed $\beta 1$-integrin (ITG1) gene expression by tenocytes. However, there might exist multiple interactions with other important uremic toxins, such as $\beta 2$-microglobulin, parathormone, neopterin, $p$-cresyl sulfate, or others, which should be analyzed in future studies.

Supplementary Materials: Supplementary materials can be found at http://www.mdpi.com/1422-0067/21/12/4241/s1. Figure S1. Metabolic activity of tenocytes treated with ciprofloxacin, as measured by alamarBlue assay after $8 \mathrm{~h}$. Figure S2. Morphology of tenocytes treated with CPX, PAA, and QA as shown by light microscopy (100× magnification). Figure S3. Tenocyte F-actin cytoskeleton after $72 \mathrm{~h}$ in response to stimulation with CPX alone and with PAA and QA, alone and in combination with CPX. Figure S4. Expression of tenocyte-associated components.

Author Contributions: Conceptualization, E.P., G.S.-T. and J. J.; methodology, E.P., B.K. and T.S.; validation, E.P. and B.K.; formal analysis, E.P.; investigation, E.P. and B.K.; resources, G.S.-T. and J.J.; data curation, E.P.; writing-original draft preparation, E.P. and G.S.-T.; writing—review and editing, E.P., B.K., J.J., T.S. and G.S.-T.; visualization, E.P. and B.K.; supervision, G.S.-T., B.K. and J.J.; project administration, G.S.-T. All authors have read and agreed to the published version of the manuscript.

Funding: J.J. was supported by grants from Deutsche Forschungsgemeinschaft (DFG) (SFB TRR 219; C-04, S-03). G.S.-T. was supported by DFG grant SCHU1979/14-1.

Acknowledgments: The authors would like to thank Ralf Stahlmann for his support.

Conflicts of Interest: The authors declare no conflicts of interest.

\section{Abbreviations}

$\begin{array}{ll}\text { CPX } & \text { ciprofloxacin } \\ \text { DAPI } & 4^{\prime}, 6^{\prime} \text {-diamidino-2-phenylindol } \\ \text { DTT } & \text { dithiothreitol } \\ \text { ECM } & \text { extracellular matrix } \\ \text { EGTA } & \text { ethylene glycol-bis(aminoethyl ether)- } N, \mathrm{~N}^{\prime} \mathrm{N}^{\prime}, \mathrm{N}^{\prime} \text {-tetraacetic acid } \\ \text { FCS } & \text { fetal calf serum } \\ \text { HEPES } & \text { 2-(4-(2-hydroxyethyl)-1-piperazine)-ethanesulfonate } \\ \text { HPRT } & \text { hypoxanthine phosphoribosyltransferase } \\ \text { IL-1 } 3 & \text { interleukin-1 beta } \\ \text { MMP } & \text { matrix metalloproteinase } \\ \text { MTT } & \text { 3-(4,5-dimethylthiazol-2-yl)-2,5diphenyltetrazoliumbromide } \\ \text { OD } & \text { optical density } \\ \text { PAA } & \text { phenylacetic acid } \\ \text { PBS } & \text { phosphate buffered saline } \\ \text { PFA } & \text { paraformaldehyde } \\ \text { PVDF } & \text { polyvinylidene fluoride } \\ \text { QA } & \text { quinolinic acid } \\ \text { RT } & \text { room temperature } \\ \text { SD } & \text { standard deviation }\end{array}$

\section{References}

1. Bailey, R.R.; Kirk, J.A.; Peddie, B.A. Norfloxacin-induced rheumatic disease. N. Z. Med. J. 1983, 96, 590. [PubMed]

2. Godoy-Santos, A.L.; Bruschini, H.; Cury, J.; Srougi, M.; de Cesar-Netto, C.; Fonseca, L.F.; Maffulli, N. Fluoroquinolones and the Risk of Achilles Tendon Disorders: Update on a Neglected Complication. Urology 2017, 113, 20-25. [CrossRef] [PubMed] 
3. Arabyat, R.M.; Raisch, D.W.; McKoy, J.M.; Bennett, C.L. Fluoroquinolone-associated tendon-rupture: A summary of reports in the Food and Drug Administration's adverse event reporting system. Expert Opin. Drug Saf. 2015, 14, 1653-1660. [CrossRef] [PubMed]

4. Mouzopoulos, G.; Stamatakos, M.; Vasiliadis, G.; Skandalakis, P. Rupture of adductor longus tendon due to ciprofloxacin. Acta Orthop. Belg. 2005, 71, 743-745.

5. Lewis, T.G. A rare case of ciprofloxacin-induced bilateral rupture of the Achilles tendon. BMJ Case Rep. 2009, 2009, bcr0820080697. [CrossRef]

6. Seidel, J.; Clarke, T.; Mathew, B. To cipro or not to cipro: Bilateral achilles ruptures with the use of quinolones. J. Am. Podiatr. Med. Assoc. 2015, 105, 185-188. [CrossRef]

7. Shybut, T.B.; Puckett, E.R. Triceps Ruptures after Fluoroquinolone Antibiotics: A Report of 2 Cases. Sports Health 2017, 9, 474-476. [CrossRef]

8. Smith, N.; Fackrell, R.; Henderson, E. Ciprofloxacin-associated bilateral iliopsoas tendon rupture: A case report. Age Ageing 2016, 45, 737-738. [CrossRef]

9. Goyal, H.; Dennehy, J.; Barker, J.; Singla, U. Achilles is not alone!!! Ciprofloxacin induced tendinopathy of gluteal tendons. QJM 2016, 109, 275-276. [CrossRef]

10. DeWolf, M.C.; Warhold, L.G. Ciprofloxacin-Induced Extensor Tendon Rupture in the Hand: A Case Report. JBJS Case Connect. 2015, 5, e301-e304. [CrossRef]

11. Shimatsu, K.; Subramaniam, S.; Sim, H.; Aronowitz, P. Ciprofloxacin-induced tendinopathy of the gluteal tendons. J. Gen. Intern. Med. 2014, 29, 1559-1562. [CrossRef] [PubMed]

12. Kawtharani, F.; Masrouha, K.Z.; Afeiche, N. Bilateral Achilles Tendon Ruptures Associated With Ciprofloxacin Use in the Setting of Minimal Change Disease: Case Report and Review of the Literature. J. Foot Ankle Surg. 2016, 55, 276-278. [CrossRef] [PubMed]

13. Alves, C.; Mendes, D.; Marques, F.B. Fluoroquinolones and the risk of tendon injury: A systematic review and meta-analysis. Eur. J. Clin. Pharmacol. 2019, 75, 1431-1443. [CrossRef] [PubMed]

14. Tempfer, H.; Traweger, A. Tendon Vasculature in Health and Disease. Front. Physiol. 2015, 6, 330. [CrossRef] [PubMed]

15. Bauge, C.; Leclercq, S.; Conrozier, T.; Boumediene, K. TOL19-001 reduces inflammation and MMP expression in monolayer cultures of tendon cells. BMC Complement. Altern. Med. 2015, 15, 217. [CrossRef]

16. Tsai, W.C.; Hsu, C.C.; Tang, F.T.; Wong, A.M.; Chen, Y.C.; Pang, J.H. Ciprofloxacin-mediated cell proliferation inhibition and G2/M cell cycle arrest in rat tendon cells. Arthritis Rheum. 2008, 58, 1657-1663. [CrossRef]

17. Tsai, W.C.; Hsu, C.C.; Chen, H.C.; Hsu, Y.H.; Lin, M.S.; Wu, C.W.; Pang, J.H. Ciprofloxacin-mediated inhibition of tenocyte migration and down-regulation of focal adhesion kinase phosphorylation. Eur. J. Pharmacol. 2009, 607, 23-26. [CrossRef] [PubMed]

18. Tsai, W.C.; Hsu, C.C.; Chen, C.P.; Chang, H.N.; Wong, A.M.; Lin, M.S.; Pang, J.H. Ciprofloxacin up-regulates tendon cells to express matrix metalloproteinase-2 with degradation of type I collagen. J. Orthop. Res. 2011, 29, 67-73. [CrossRef]

19. Chang, H.N.; Pang, J.H.; Chen, C.P.; Ko, P.C.; Lin, M.S.; Tsai, W.C.; Yang, Y.M. The effect of aging on migration, proliferation, and collagen expression of tenocytes in response to ciprofloxacin. J. Orthop. Res. 2012, 30, 764-768. [CrossRef]

20. Kempka, G.; Ahr, H.J.; Ruther, W.; Schluter, G. Effects of fluoroquinolones and glucocorticoids on cultivated tendon cells in vitro. Toxicol. In Vitro 1996, 10, 743-754. [CrossRef]

21. Fox, A.J.; Schar, M.O.; Wanivenhaus, F.; Chen, T.; Attia, E.; Binder, N.B.; Otero, M.; Gilbert, S.L.; Nguyen, J.T.; Chaudhury, S.; et al. Fluoroquinolones impair tendon healing in a rat rotator cuff repair model: A preliminary study. Am. J. Sports Med. 2014, 42, 2851-2859. [CrossRef] [PubMed]

22. Menon, A.; Pettinari, L.; Martinelli, C.; Colombo, G.; Portinaro, N.; Dalle-Donne, I.; d'Agostino, M.C.; Gagliano, N. New insights in extracellular matrix remodeling and collagen turnover related pathways in cultured human tenocytes after ciprofloxacin administration. Muscles Ligaments Tendons J. 2013, 3, 122-131. [PubMed]

23. Corps, A.N.; Harrall, R.L.; Curry, V.A.; Hazleman, B.L.; Riley, G.P. Contrasting effects of fluoroquinolone antibiotics on the expression of the collagenases, matrix metalloproteinases (MMP)-1 and -13, in human tendon-derived cells. Rheumatology (Oxford) 2005, 44, 1514-1517. [CrossRef] [PubMed]

24. Egerbacher, M.; Edinger, J.; Tschulenk, W. Effects of enrofloxacin and ciprofloxacin hydrochloride on canine and equine chondrocytes in culture. Am. J. Vet. Res. 2001, 62, 704-708. [CrossRef] 
25. Bisaccia, D.R.; Aicale, R.; Tarantino, D.; Peretti, G.M.; Maffulli, N. Biological and chemical changes in fluoroquinolone-associated tendinopathies: A systematic review. Br. Med. Bull. 2019, 130, 39-49. [CrossRef]

26. Lowes, D.A.; Wallace, C.; Murphy, M.P.; Webster, N.R.; Galley, H.F. The mitochondria targeted antioxidant MitoQ protects against fluoroquinolone-induced oxidative stress and mitochondrial membrane damage in human Achilles tendon cells. Free Radic. Res. 2009, 43, 323-328. [CrossRef]

27. Kaleagasioglu, F.; Olcay, E. Fluoroquinolone-induced tendinopathy: Etiology and preventive measures. Tohoku J. Exp. Med. 2012, 226, 251-258. [CrossRef]

28. Juras, V.; Winhofer, Y.; Szomolanyi, P.; Vosshenrich, J.; Hager, B.; Wolf, P.; Weber, M.; Luger, A.; Trattnig, S. Multiparametric MR Imaging Depicts Glycosaminoglycan Change in the Achilles Tendon during Ciprofloxacin Administration in Healthy Men: Initial Observation. Radiology 2015, 275, 763-771. [CrossRef]

29. Nguyen, T.; Gelband, K. A Case-Based Approach to Evaluate the Potential Risks Associated with Fluoroquinolones and Steroids. Consult Pharm. 2016, 31, 646-649. [CrossRef]

30. Tam, P.K.; Ho, C.T. Fluoroquinolone-induced Achilles tendinitis. Hong Kong Med. J. 2014, 20, 545-547. [CrossRef]

31. Meneghello, A.; Bertoli, M. Tendon disease and adjacent bone erosion in dialysis patients. Br. J. Radiol. 1983, 56, 915-920. [CrossRef] [PubMed]

32. Bhole, R.; Flynn, J.C.; Marbury, T.C. Quadriceps tendon ruptures in uremia. Clin. Orthop. Relat. Res. 1985, 195, 200-206. [CrossRef]

33. Rivera, M.; Teruel, J.L.; Naya, M.T.; Ortuno, J. Bilateral rupture of the quadriceps tendon in uremia. Rev. Clin. Esp. 1991, 189, 348. [PubMed]

34. Schenkier, S.L.; Gertner, E. Massive soft tissue calcification causing complete loss of extensor tendon function in renal failure. J. Rheumatol. 1992, 19, 1640-1642.

35. Gao, M.F.; Yang, H.L.; Shi, W.D. Simultaneous bilateral quadriceps tendon rupture in a patient with hyperparathyroidism undergoing long-term haemodialysis: A case report and literature review. J. Int. Med. Res. 2013, 41, 1378-1383. [CrossRef] [PubMed]

36. Yudd, M.; Llach, F. Current medical management of secondary hyperparathyroidism. Am. J. Med. Sci. 2000, 320, 100-106. [CrossRef]

37. Niwa, T. Targeting protein-bound uremic toxins in chronic kidney disease. Expert Opin. Ther. Targets 2013, 17, 1287-1301. [CrossRef]

38. Niwa, T.; Yoshizumi, H.; Emoto, Y.; Miyazaki, T.; Hashimoto, N.; Takeda, N.; Tatematsu, A.; Maeda, K. Accumulation of quinolinic acid in uremic serum and its removal by hemodialysis. Clin. Chem. 1991, 37, 159-161. [CrossRef]

39. Jourde-Chiche, N.; Dou, L.; Cerini, C.; Dignat-George, F.; Vanholder, R.; Brunet, P. Protein-bound toxins-update 2009. Semin. Dial 2009, 22, 334-339. [CrossRef]

40. Trotman, R.L.; Williamson, J.C.; Shoemaker, D.M.; Salzer, W.L. Antibiotic dosing in critically ill adult patients receiving continuous renal replacement therapy. Clin. Infect. Dis. 2005, 41, 1159-1166. [CrossRef]

41. Saldanha, J.F.; Yi, D.; Stockler-Pinto, M.B.; Soula, H.A.; Chambert, S.; Fouque, D.; Mafra, D.; Soulage, C.O. Determination of the binding properties of the uremic toxin phenylacetic acid to human serum albumin. Biochimie 2016, 125, 53-58. [CrossRef] [PubMed]

42. Cohen, G.; Raupachova, J.; Horl, W.H. The uraemic toxin phenylacetic acid contributes to inflammation by priming polymorphonuclear leucocytes. Nephrol. Dial Transpl. 2013, 28, 421-429. [CrossRef] [PubMed]

43. Schmidt, S.; Westhoff, T.H.; Krauser, P.; Ignatius, R.; Jankowski, J.; Jankowski, V.; Zidek, W.; van der Giet, M. The uraemic toxin phenylacetic acid impairs macrophage function. Nephrol. Dial Transpl. 2008, 23, 3485-3493. [CrossRef] [PubMed]

44. Morita, M.; Yano, S.; Yamaguchi, T.; Yamauchi, M.; Sugimoto, T. Phenylacetic acid stimulates reactive oxygen species generation and tumor necrosis factor-alpha secretion in vascular endothelial cells. Ther. Apher. Dial 2011, 15, 147-150. [CrossRef] [PubMed]

45. Yano, S.; Yamaguchi, T.; Kanazawa, I.; Ogawa, N.; Hayashi, K.; Yamauchi, M.; Sugimoto, T. The uraemic toxin phenylacetic acid inhibits osteoblastic proliferation and differentiation: An implication for the pathogenesis of low turnover bone in chronic renal failure. Nephrol. Dial Transpl. 2007, 22, 3160-3165. [CrossRef] [PubMed] 
46. Jankowski, J.; van der Giet, M.; Jankowski, V.; Schmidt, S.; Hemeier, M.; Mahn, B.; Giebing, G.; Tolle, M.; Luftmann, H.; Schluter, H.; et al. Increased plasma phenylacetic acid in patients with end-stage renal failure inhibits iNOS expression. J. Clin. Investig. 2003, 112, 256-264. [CrossRef] [PubMed]

47. Pawlak, K.; Brzosko, S.; Mysliwiec, M.; Pawlak, D. Kynurenine, quinolinic acid-The new factors linked to carotid atherosclerosis in patients with end-stage renal disease. Atherosclerosis 2009, 204, 561-566. [CrossRef]

48. Pawlak, D.; Koda, M.; Pawlak, S.; Wolczynski, S.; Buczko, W. Contribution of quinolinic acid in the development of anemia in renal insufficiency. Am. J. Physiol. Renal. Physiol. 2003, 284, F693-F700. [CrossRef]

49. Kawashima, Y.; Sanaka, T.; Sugino, N.; Takahashi, M.; Mizoguchi, H. Suppressive effect of quinolinic acid and hippuric acid on bone marrow erythroid growth and lymphocyte blast formation in uremia. Adv. Exp. Med. Biol. 1987, 223, 69-72.

50. Tsai, W.C.; Yang, Y.M. Fluoroquinolone-associated tendinopathy. Chang Gung Med. J. 2011, 34, 461-467.

51. Hirata, C.A.; Guay, D.R.; Awni, W.M.; Stein, D.J.; Peterson, P.K. Steady-state pharmacokinetics of intravenous and oral ciprofloxacin in elderly patients. Antimicrob. Agents Chemother. 1989, 33, 1927-1931. [CrossRef] [PubMed]

52. Roberts, D.M.; Roberts, J.A.; Roberts, M.S.; Liu, X.; Nair, P.; Cole, L.; Lipman, J.; Bellomo, R.; RENAL Replacement Therapy Study Investigators. Variability of antibiotic concentrations in critically ill patients receiving continuous renal replacement therapy: A multicentre pharmacokinetic study. Crit. Care Med. 2012, 40, 1523-1528. [CrossRef] [PubMed]

53. Gonzalez, M.A.; Uribe, F.; Moisen, S.D.; Fuster, A.P.; Selen, A.; Welling, P.G.; Painter, B. Multiple-dose pharmacokinetics and safety of ciprofloxacin in normal volunteers. Antimicrob. Agents Chemother. 1984, 26, 741-744. [CrossRef] [PubMed]

54. Tasoglu, O.; Ekiz, T.; Yenigun, D.; Akyuz, M.; Ozgirgin, N. Bilateral quadriceps and triceps tendon rupture in a hemodialysis patient. Hemodial. Int. 2016, 20, E19-E21. [CrossRef]

55. Tao, Z.; Liu, W.; Ma, W.; Luo, P.; Zhi, S.; Zhou, R. A simultaneous bilateral quadriceps and patellar tendons rupture in patients with chronic kidney disease undergoing long-term hemodialysis: A case report. BMC Musculoskelet. Disord. 2020, 21, 179. [CrossRef]

56. Wu, W.; Wang, C.; Ruan, J.; Wang, H.; Huang, Y.; Zheng, W.; Chen, F. Simultaneous spontaneous bilateral quadriceps tendon rupture with secondary hyperparathyroidism in a patient receiving hemodialysis: A case report. Medicine (Baltimore) 2019, 98, e14809. [CrossRef]

57. Zribi, W.; Zribi, M.; Guidara, A.R.; Ben Jemaa, M.; Abid, A.; Krid, N.; Naceur, A.; Keskes, H. Spontaneous and simultaneous complete bilateral rupture of the quadriceps tendon in a patient receiving hemodialysis: A case report and literature review. World J. Orthop. 2018, 9, 180-184. [CrossRef]

58. Torkaman, A.; Yousof Gomrokchi, A.; Elahifar, O.; Barmayoon, P.; Shojaei, S.F. Simultaneous bilateral rupture of patellar tendons in diabetic hemodialysis patient: A case report. Caspian J. Intern. Med. 2018, 9, 306-311.

59. Moerenhout, K.; Gkagkalis, G.; Benoit, B.; Laflamme, G.Y. Simultaneous Ipsilateral Quadriceps and Triceps Tendon Rupture in a Patient with End-Stage Renal Failure. Case Rep. Orthop. 2018, 2018, 7602096. [CrossRef]

60. Artan, A.S.; Basgoze, B. Bilateral quadriceps tendon rupture in a hemodialysis patient. Clin. Exp. Nephrol. 2015, 19, 755-756. [CrossRef]

61. Vemuri, V.N.; Venkatesh, M.; Kada, V.; Chakkalakkoombil, S.V. Spontaneous bilateral quadriceps tendon rupture in a patient with renal failure. BMJ Case Rep. 2018, 2018, bcr-2017. [CrossRef] [PubMed]

62. Medhi, B.; Kaur, H.; Prakash, A. Effect of ciprofloxacin-mediated inhibition on cell proliferation in rat tendon cells: Comment on the article by Tsai et al. Arthritis Rheum. 2009, 60, 1564. [CrossRef] [PubMed]

63. Pawlak, D.; Tankiewicz, A.; Buczko, W. Kynurenine and its metabolites in the rat with experimental renal insufficiency. J. Physiol. Pharmacol. 2001, 52, 755-766. [PubMed]

64. Pawlak, D.; Tankiewicz, A.; Mysliwiec, P.; Buczko, W. Tryptophan metabolism via the kynurenine pathway in experimental chronic renal failure. Nephron 2002, 90, 328-335. [CrossRef] [PubMed]

65. Sallee, M.; Dou, L.; Cerini, C.; Poitevin, S.; Brunet, P.; Burtey, S. The aryl hydrocarbon receptor-activating effect of uremic toxins from tryptophan metabolism: A new concept to understand cardiovascular complications of chronic kidney disease. Toxins (Basel) 2014, 6, 934-949. [CrossRef]

66. Sendzik, J.; Shakibaei, M.; Schafer-Korting, M.; Lode, H.; Stahlmann, R. Synergistic effects of dexamethasone and quinolones on human-derived tendon cells. Int. J. Antimicrob. Agents 2010, 35, 366-374. [CrossRef]

67. Calderwood, D.A. Integrin activation. J. Cell Sci. 2004, 117, 657-666. [CrossRef] 
68. Bellis, S.L. Variant glycosylation: An underappreciated regulatory mechanism for beta1 integrins. Biochim. Biophys. Acta 2004, 1663, 52-60. [CrossRef]

69. Fiorucci, S.; Lin, X.; Sadoul, K.; Fournet, G.; Bouvard, D.; Vinogradova, O.; Joseph, B.; Block, M.R. Targeting Integrin-Dependent Adhesion and Signaling with 3-Arylquinoline and 3-Aryl-2-Quinolone Derivatives: A new Class of Integrin Antagonists. PLoS ONE 2015, 10, e0141205. [CrossRef]

70. Bidone, T.C.; Skeeters, A.V.; Oakes, P.W.; Voth, G.A. Multiscale model of integrin adhesion assembly. PLoS Comput. Biol. 2019, 15, e1007077. [CrossRef]

71. Del Buono, A.; Oliva, F.; Longo, U.G.; Rodeo, S.A.; Orchard, J.; Denaro, V.; Maffulli, N. Metalloproteases and rotator cuff disease. J. Shoulder Elbow Surg. 2012, 21, 200-208. [CrossRef] [PubMed]

72. Corps, A.N.; Harrall, R.L.; Curry, V.A.; Fenwick, S.A.; Hazleman, B.L.; Riley, G.P. Ciprofloxacin enhances the stimulation of matrix metalloproteinase 3 expression by interleukin-1beta in human tendon-derived cells. A potential mechanism of fluoroquinolone-induced tendinopathy. Arthritis Rheum. 2002, 46, 3034-3040. [CrossRef] [PubMed]

73. Sodersten, F.; Hultenby, K.; Heinegard, D.; Johnston, C.; Ekman, S. Immunolocalization of collagens (I and III) and cartilage oligomeric matrix protein in the normal and injured equine superficial digital flexor tendon. Connect. Tissue Res. 2013, 54, 62-69. [CrossRef] [PubMed]

74. Heinemeier, K.M.; Schjerling, P.; Heinemeier, J.; Magnusson, S.P.; Kjaer, M. Lack of tissue renewal in human adult Achilles tendon is revealed by nuclear bomb (14)C. FASEB J. 2013, 27, 2074-2079. [CrossRef] [PubMed]

75. Heinemeier, K.M.; Schjerling, P.; Ohlenschlaeger, T.F.; Eismark, C.; Olsen, J.; Kjaer, M. Carbon-14 bomb pulse dating shows that tendinopathy is preceded by years of abnormally high collagen turnover. FASEB J. 2018, 32, 4763-4775. [CrossRef] [PubMed]

76. Berkoff, D.J.; Kallianos, S.A.; Eskildsen, S.M.; Weinhold, P.S. Use of an IL1-receptor antagonist to prevent the progression of tendinopathy in a rat model. J. Orthop. Res. 2016, 34, 616-622. [CrossRef] [PubMed]

77. Corps, A.N.; Curry, V.A.; Harrall, R.L.; Dutt, D.; Hazleman, B.L.; Riley, G.P. Ciprofloxacin reduces the stimulation of prostaglandin $\mathrm{E}(2)$ output by interleukin-1beta in human tendon-derived cells. Rheumatology (Oxford) 2003, 42, 1306-1310. [CrossRef]

78. Pfaffl, M.W. A new mathematical model for relative quantification in real-time RT-PCR. Nucleic Acids Res. 2001, 29, e45. [CrossRef] 